\title{
The Association between Neutrophil to Lymphocyte Ratio and Systolic Right Ventricular Dysfunction in Patients with Acute Inferior ST- Segment Elevation Myocardial Infarction
}

\author{
MOHAMED S. AMER, M.Sc.; IBTESAM KHAIRAT, M.D.; MOHAMED A. ABD ELAAL, M.D. and \\ SEHAM F. BADR, M.D.
}

The Department of Cardiology, Faculty of Medicine, Tanta University

\begin{abstract}
Background: Ischemic heart disease is considered the most common cause of death worldwide. Inflammation and oxidative stress play an important role in the pathogenesis of all phases of atherosclerosis and atherosclerotic plaque rupture which are the main mechanisms in the pathophysiology of acute ST-segment Elevation Myocardial Infarction (STEMI). Acute inferior STEMI is associated with increased in-hospital morbidity and mortality particularly among patients with coexisting Right Ventricular (RV) involvement. High Neutrophil to Lymphocyte Ratio (NLR) is an independent predictor of major adverse cardiac events and mortality in patients with myocardial infarction.
\end{abstract}

Aim of Study: To study the relationship between the NLR and RV Dysfunction (RVD) in patients with inferior STEMI who underwent primary Percutaneous Coronary Intervention (PCI) or received fibrinolytic therapy. RVD measured by Tricuspid Annular Plane Systolic Excursion (TAPSE) $<16$ $\mathrm{mm}$ and Tissue Doppler Imaging (TDI) S wave $<10 \mathrm{~cm} / \mathrm{s}$ [1]

Patients and Methods: This study was conducted on sixty patients diagnosed with acute inferior STEMI and underwent primary PCI or received fibrinolytic therapy in Tanta University Hospitals, Cardiovascular Department, from December 2017 to June 2018. The cases were divided into two groups according to the presence of RVD or not. The groups were compared according to NLR and Receiver Operating Characteristic (ROC) analysis was performed to access the predictability of high NLR in patients with RVD.

Results: The NLR was significantly higher in the group with RVD compared to that without RVD $(p=0.002)$. In ROC analysis, NLR $>3.2$ predicted RVD with sensitivity of $82.16 \%$ and specificity of $89.19 \%$. In a multivariate regression analysis, NLR remained an independent predictor of RVD (95\% C.I $0.787-0.976, p=0.002$ ).

Conclusion: NLR was an independent predictor of RVD in patients with acute inferior STEMI who underwent primary PCI or received fibrinolytic therapy.

Key Words: Neutrophil - Lymphocyte Ratio - ST-Segment elevation myocardial infarction.

Correspondence to: Dr. Mohamed S. Amer, The Department of Cardiology, Faculty of Medicine, Tanta University

\section{Introduction}

ISCHAEMIC heart disease is the most common cause of death and its frequency is increasing [2] The primary goal in management of acute STsegment Elevation Myocardial Infarction (STEMI) is reperfusion therapy with intravenous fibrinolysis or Primary Percutaneous Intervention (PCI) [3] Autopsy findings showed that RV involvement is observed in up to $50 \%$ of patients with inferior STEMI [4] . Acute inferior STEMI is associated with increased in-hospital morbidity and mortality particularly among patients with coexisting RV dysfunction [1-5]. Inflammation plays an important role in the pathogenesis and progression of the atherosclerosis [6]. The Neutrophil to Lymphocyte Ratio (NLR) shows balance between neutrophil and lymphocyte levels and can be used as an indicator of systemic inflammation. High NLR is a predictor of major adverse cardiac events and mortality in patients with acute Myocardial Infarction (MI) [7].

Aim of the work: Was to assess the relationship between NLR and systolic RVD in patients with acute inferior STEMI who underwent primary PCI or received fibrinolytic therapy.

\section{Patients and Methods}

The study included 60 patients diagnosed with acute inferior STEMI according to recent 2017 European Society of cardiology guidelines [2] and presenting to the Cardiology Department at Tanta University Hospital. All patients underwent primary PCI or received fibrinolytic therapy. The study was done in a period of six months starting from December 2017 to June 2018. The included cases were divided into two groups according to RVD 
measured by TAPSE and TDI S wave: Group 1 comprised 37 patients in whom patients had normal RV function, (TAPSE $>16 \mathrm{~mm}$ and TDI $\mathrm{S}$ wave $>10 \mathrm{~cm} / \mathrm{s}$ ) and Group 2 comprised 23 patients in whom patients had RVD, (TAPSE <16mm and TDI $S$ wave $<10 \mathrm{~cm} / \mathrm{s}$ ) [1]. Total and differential White Blood Cells (WBCs) count and echocardiography were done to all patients during admission.

Comparison between the two groups was done during hospitalization according to age, sex, risk factors as Diabetes Mellitus (DM), Hypertension (HTN), smoking, dyslipidaemia, laboratory findings as WBCs count with differentiation (total leucocytic count, neutrophil count, lymphocyte count, neutrophil to lymphocyte ratio), echocardiographic findings (Left Ventricle (LV) ejection fraction, RV mid-way diameter) and type of reperfusion (primary PCI or fibrinolytic therapy).

Exclusion criteria: Included patients with prior myocardial infarction, patients who previously underwent Coronary Artery Bypass Graft (CABG) or PCI, patients with end stage renal failure (creatinine clearance $<15 \mathrm{~mL} / \mathrm{min}$ ), patients with hematological disorders, patients with active hepatobiliary disease, patients with active infections, patients with neoplastic diseases and patients with recent major surgical procedure or trauma.

Duration of the study: This study was done in a period of six months starting from December 2017 to June 2018.

\section{Statistical analysis:}

Data were fed to the computer and analyzed using IBM SPSS software package Version 20.0. Qualitative data were described using number and percent. Quantitative data were described using range (minimum and maximum), mean, standard deviation and median. Significance of the obtained results was judged at the $5 \%$ level. Student $t$-test for normally distributed quantitative variables, to compare between two studied groups. ROC analysis was performed to select cut-off values with suitable sensitivity and specificity to detect factor affecting $\mathrm{RV}$ function. Univariate and multivariate analysis were performed to investigate the possible predictive factor affecting RV function.

\section{Results}

\section{Patient demographics:}

Twenty two patients (40\%) of the study population were males and 36 patients $(60 \%)$ were females. There was no statistically significant difference between the both groups $(p$-value $=$ 0.914).
The age of the study population ranged from 31 to 78 years. The age of patients in Group I ranged from 31.0 to 74.0 years, with a mean age of 55.49 \pm 11.32 years, while in Group II the age ranged from 35.0 to 78.0 years with a mean \pm SD age of $54.70 \pm 11.98$ years. There was no statistically significant difference between both groups regarding age $(p$-value $=0.798)$.

\section{Prevalence of risk factors:}

Table (1) show the prevalence of risk factors in the studied groups. There was no statistically significant difference between both groups.

Type of therapy: Fourteen patients (37.8\%) received fibrinolytic therapy, while primary PCI was done for $23(62.2 \%)$ patients in Group I, while 8 patients $(34.8 \%)$ received fibrinolytic therapy. Primary PCI was done for 15 patients in Group II $(65.2 \%)$. There was no statistically significant difference between both groups $(p$-value $=0.811)$ (Table 1).

Table (1): Comparison between the two studied groups according to risk factors and type of reperfusion.

\begin{tabular}{|c|c|c|c|c|c|c|}
\hline & \multicolumn{2}{|c|}{$\begin{array}{l}\text { Group I } \\
(n=37)\end{array}$} & \multicolumn{2}{|c|}{$\begin{array}{c}\text { Group II } \\
(n=23)\end{array}$} & \multirow{2}{*}{$x^{2}$} & \multirow{2}{*}{$p$} \\
\hline & No. & $\%$ & No. & $\%$ & & \\
\hline \multicolumn{7}{|l|}{ Hypertension: } \\
\hline No & 20 & 54.1 & 8 & 34.8 & 2.116 & 0.146 \\
\hline Yes & 17 & 45.9 & 15 & 65.2 & & \\
\hline \multicolumn{7}{|c|}{ Diabetes Mellitus: } \\
\hline No & 21 & 56.8 & 11 & 47.8 & 0.455 & 0.500 \\
\hline Yes & 16 & 43.2 & 12 & 52.2 & & \\
\hline \multicolumn{7}{|l|}{ Smoker: } \\
\hline No & 19 & 51.4 & 12 & 52.2 & 0.004 & 0.951 \\
\hline Yes & 18 & 48.6 & 11 & 47.8 & & \\
\hline \multicolumn{7}{|l|}{ Dyslipidemia: } \\
\hline No & 17 & 45.9 & 9 & 39.1 & 0.268 & 0.604 \\
\hline Yes & 20 & 54.1 & 14 & 60.9 & & \\
\hline \multicolumn{7}{|c|}{ Type of reperfusion: } \\
\hline Fibrinolytic & 14 & 37.8 & 8 & 34.8 & 0.057 & 0.811 \\
\hline $\mathrm{pPCI}$ & 23 & 62.2 & 15 & 65.2 & & \\
\hline
\end{tabular}

\section{Laboratory parameters: Table (2):}

The neutrophil count ranged from 2418.0 to $9300.0 \mathrm{cell} / \mathrm{mm}_{3}$ with a mean count of $5349.70 \pm$ $1792.27 \mathrm{cell} / \mathrm{mm}^{3}$ in Group I, while the neutrophil count ranged from 3392.0 to 11234.0 cell $/ \mathrm{mm}_{3}$ with a mean count of $7101.87 \pm 1911.84 \mathrm{cell} / \mathrm{mm}$ in Group II. Neutrophil count was statistically significant higher in Group II than Group I ( $p$ value $=0.001$ )

The lymphoुcyte count ranged from 645.0 to $4080.0 \mathrm{cell} / \mathrm{mm}_{3}$, with a mean count of $2333.03 \pm$ $977.71 \mathrm{cell} / \mathrm{mm}$ in Group I, while the Lymphocyte 
count ranged from 1014.0 to $3920.0 \mathrm{cell} / \mathrm{mm}^{3}{ }^{3}$, with a mean count of $1958.83 \pm 759.98 \mathrm{cell} / \mathrm{mm}^{3}$ in Group II. There was no statistically significant difference between both groups ( $p$-value=0.136).

The TLC count ranged from 3900 to 12600 cell $/ \mathrm{mm}^{3}$, with a mean count of $8130 \pm 2460$ cell/ $\mathrm{mm}^{3}$ in Group I, while the TLC count ranged from 5300 to 13700 cell $/ \mathrm{mm}^{3}$, with a mean count of 9570 $\pm 2030 \mathrm{cell} / \mathrm{mm}^{3}$ in Group II. TLC count was statistically significant higher in Group II than Group I $(p$-value $=0.021)$.

The N/L Ratio ranged from 1.0 to 8.50 , with a mean of $2.68 \pm 1.52$ in Group I, while the N/L Ratio ranged from 1.57 to 6.90 , with a mean of $4.08 \pm$ 1.65 in Group II. NLR was statistically significant higher in Group II than Group I ( $p$-value=0.002) (Table 2).

Table (2): Comparison between both groups according to laboratory parameters.

\begin{tabular}{|c|c|c|c|c|}
\hline & \multicolumn{2}{|c|}{ RV Dysfunction } & \multirow{2}{*}{$\begin{array}{c}\text { Test } \\
\text { of sig. }\end{array}$} & \multirow[b]{2}{*}{$p$} \\
\hline & $\begin{array}{l}\text { Group I } \\
(n=37)\end{array}$ & $\begin{array}{c}\text { Group II } \\
(n=23)\end{array}$ & & \\
\hline $\begin{array}{l}\text { Neutrophil coun } \\
\left(\text { cell/mm }^{3}\right): \\
\text { Min.-max. } \\
\text { Mean } \pm \text { SD. } \\
\text { Median }\end{array}$ & $\begin{array}{l}2418.0-9300.0 \\
5349.70 \pm 1792.27 \\
5183.0\end{array}$ & $\begin{array}{l}3392.0-11234.0 \\
7101.87 \pm 1911.84 \\
6800.0\end{array}$ & $\begin{array}{l}t= \\
3.589 *\end{array}$ & $0.001 *$ \\
\hline $\begin{array}{l}\text { Lymphocyte } \\
\text { count } \\
\left.\text { (cell/mm }{ }^{3}\right) \text { : } \\
\text { Min.-max. } \\
\text { Mean } \pm \text { SD. } \\
\text { Median }\end{array}$ & $\begin{array}{l}645.0-4080.0 \\
2333.03 \pm 977.71 \\
2280.0\end{array}$ & $\begin{array}{l}1014.0-3920.0 \\
1958.83 \pm 759.98 \\
1728.0\end{array}$ & $\begin{array}{l}\mathrm{U}= \\
327.50\end{array}$ & 0.136 \\
\hline $\begin{array}{l}\text { NLR: } \\
\quad \text { Min.-max. } \\
\quad \text { Mean } \pm \text { SD. } \\
\quad \text { Median }\end{array}$ & $\begin{array}{l}1.0-5.33 \\
2.31 \pm 1.0 \\
2.10\end{array}$ & $\begin{array}{l}1.70-8.50 \\
4.68 \pm 1.59 \\
5.0\end{array}$ & $\begin{array}{l}\mathrm{U}= \\
101.0^{*}\end{array}$ & $0.001 *$ \\
\hline $\begin{array}{l}\text { TLC count } \\
\left(\text { cell/mm }^{\prime}\right): \\
\text { Min.-max. } \\
\text { Mean } \pm \text { SD. } \\
\text { Median }\end{array}$ & $\begin{array}{l}3.90-12.60 \\
8.13 \pm 2.46 \\
8.30\end{array}$ & $\begin{array}{l}5.30-13.70 \\
9.57 \pm 2.03 \\
9.70\end{array}$ & $\begin{array}{l}t= \\
2.366^{*}\end{array}$ & $0.021 *$ \\
\hline $\begin{array}{ll}t & : \text { Student } \\
\mathrm{U} & : \text { Student } \\
p & : p \text {-value } \\
& \text { RVD. } \\
& : \text { Statistic } \\
\text { NLR } & : \text { Neutrop } \\
\text { Min } & : \text { Minimu } \\
\text { Max } & : \text { Maxim } \\
\text { SD } & : \text { Standar }\end{array}$ & $\begin{array}{l}\text { t-test. } \\
\text {-test. } \\
\text { cor comparing bety } \\
\text { lly significant at } \\
\text { hil to Lymphocyte } \\
\text { n. } \\
\text { m. } \\
\text { Deviation. }\end{array}$ & $\begin{array}{l}\text { veen Normal RV f } \\
\text { Ratio. } \\
\end{array}$ & Inction & and \\
\hline
\end{tabular}

\section{Echocardiographic findings: Table (3):}

The EF ranged from 49.0 to $72.0 \%$ with a mean of $58.16 \pm 4.62 \%$ in Group I, while the EF ranged from 45.0 to $66.0 \%$, with a mean of $53.30 \pm 5.39 \%$ in Group II. EF was statistically significant lowered in Group II than Group I ( $p$-value=0.001).
The RV mid-way diameter ranged from 23.0 to $34.0 \mathrm{~mm}$, with a mean of $27.03 \pm 2.65 \mathrm{~mm}$ in Group I, while the RV mid-way diameter ranged from 24.0 to $33.0 \mathrm{~mm}$, with a mean of $28.83 \pm$ $2.92 \mathrm{~mm}$ in Group II. RV mid-way diameter was statistically significant larger in Group II than Group I ( $p$-value=0.017).

The left atrium size ranged from 3.20 to 4.60 $\mathrm{cm}$ with a mean of $3.86 \pm 0.39 \mathrm{~cm}$ in Group I, while the (LA) size ranged from 3.0 to $4.50 \mathrm{~cm}$ with a mean of $3.86 \pm 0.37 \mathrm{~cm}$ in Group II. ( $p$-value $=0.956)$. There was no statistically significant difference between both groups (Table 3 ).

Table (3): Comparison between the two studied groups according to echocardiographic parameters.

\begin{tabular}{|c|c|c|c|c|}
\hline & \multicolumn{2}{|c|}{ Patient population $=60$} & \multirow[b]{2}{*}{$t$} & \multirow[b]{2}{*}{$p$} \\
\hline & $\begin{array}{l}\text { Group I } \\
(n=37)\end{array}$ & $\begin{array}{c}\text { Group II } \\
(n=23)\end{array}$ & & \\
\hline \multicolumn{5}{|l|}{$E F(\%):$} \\
\hline Min.-max. & $49.0-72.0$ & $45.0-66.0$ & $3.716^{*}$ & $0.001 *$ \\
\hline Mean $\pm \mathrm{SD}$ & $58.16 \pm 4.62$ & $53.30 \pm 5.39$ & & \\
\hline Median & 58.0 & 53.0 & & \\
\hline \multicolumn{5}{|l|}{$R V$ mid-way } \\
\hline \multicolumn{5}{|l|}{ diameter $(\mathrm{mm})$ : } \\
\hline Min.-max. & $23.0-34.0$ & $24.0-33.0$ & $2.459 *$ & $0.017 *$ \\
\hline Mean $\pm \mathrm{SD}$ & $27.03 \pm 2.65$ & $28.83 \pm 2.92$ & & \\
\hline Median & 27.0 & 29.0 & & \\
\hline LA size $(\mathrm{cm})$ : & & & 0.055 & \\
\hline Min.-max. & $3.20-4.60$ & $3.0-4.50$ & & 0.956 \\
\hline Mean \pm SD. & $3.86 \pm 0.39$ & $3.86 \pm 0.37$ & & \\
\hline Median & 4.0 & 4.0 & & \\
\hline
\end{tabular}

Univariate and multivariate analysis for the parameters affecting $R V$ dysfunction:

Univariate and multivariate analysis were performed to investigate the possible predictive factor affecting RVD. In univariate analysis, sex, age, HTN, DM, smoking, dyslipidemia, neutrophil count, lymphocyte count, N/L ratio, TLC count, $\mathrm{EF}, \mathrm{RV}$ midway diameter and LA size were correlated with RVD (Table 4).

In the multivariate analysis, using model adjusted for previously mentioned parameters, (neutrophil count, N/L ratio, TLC count, EF and RV mid-way diameter) independently predicted RVD.

The Receiver Operating Characteristic (ROC) analysis showing the performance and predictive accuracy of N/L ratio in prediction of right ventricular dysfunction; AUC was 0.881 with cut off value of NLR >3.2, with $82.61 \%$ sensitivity and $89.19 \%$ specificity. 
Table (4): Univariate and multivariate analysis for the parameters affecting dysfunction $(n=60)$.

\begin{tabular}{llccc}
\hline & \multicolumn{2}{c}{ Univariate } & \#Multivariate \\
\cline { 2 - 5 } & \multicolumn{1}{c}{$p$} & OR (95\%C.I) & $p$ & OR (95\%C.I) \\
\hline - Sex (female) & 0.914 & $1.061(0.366-3.073)$ & & \\
- Age (years) & 0.794 & $0.994(0.950-1.040)$ & & \\
- Hypertension & 0.149 & $2.206(0.753-6.459)$ & & \\
- Diabetes mellitus & 0.501 & $1.432(0.503-4.072)$ & & \\
- Smoker & 0.951 & $0.968(0.341-2.742)$ & & \\
- Dyslipidaemia & 0.605 & $1.322(0.459-3.809)$ & & \\
- Neutrophil count (cell/mm3) & $0.002^{*}$ & $1.001(1.000-1.001)$ & 0.223 & $0.998(0.996-1.001)$ \\
- Lymphocyte count cell/mm3) & 0.126 & $1.000(0.999-1.000)$ & & \\
- Neutrophil to Lymphocyte Ratio (NLR) & $<0.001 *$ & $3.462(1.957-6.127)$ & $0.013 *$ & $5.208(1.424-19.054)$ \\
- TLC count (cell/mm3) & $0.027 *$ & $1.324(1.032-1.697)$ & 0.136 & $4.710(0.613-36.193)$ \\
- Ejection fraction (EF) (\%) & $0.002^{*}$ & $0.809(0.707-0.925)$ & 0.092 & $0.830(0.669-1.031)$ \\
- Right ventricle mid-way diameter (mm) & $0.022^{*}$ & $1.267(1.035-1.551)$ & 0.890 & $1.025(0.727-1.445)$ \\
- Left atrium size (cm) & 0.955 & $0.961(0.243-3.805)$ & & \\
- Number of vessels & 0.205 & $1.427(0.823-2.472)$ & & \\
\hline
\end{tabular}

OR: Odd's ratio.

C.I: Confidence Interval.

All variables with $p<0.05$ was included in the multivariate.

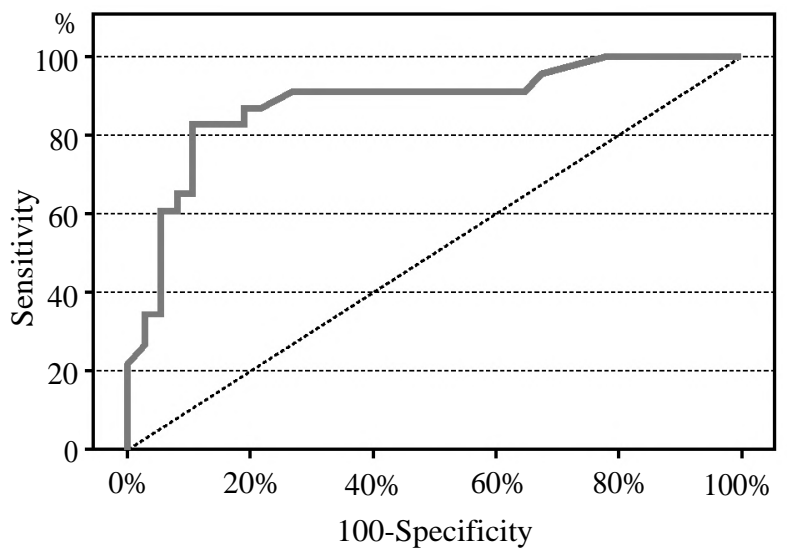

Discussion

Ischemic heart disease is the most common leading cause of death worldwide and its frequency is increasing [2]. Recent studies have demonstrated a better prognosis following STEMI with greater use of reperfusion therapy, primary PCI, modern antithrombotic therapy, and secondary prevention [8]. Atherosclerosis and atherosclerotic plaque rupture are the main causes of STEMI. Inflammation plays an important role in formation of atherosclerosis and may lead to plaque rupture in the presence of several risk factors [9]. Several factors involve impairment of perfusion at tissue level after STEMI. These are white blood cell and platelet accumulation in capillaries, inflammation-driven complex neutrophil and platelet interactions, reactive oxygen radicals, distal thrombus embolization, and endothelial dysfunction due to ischemia and reperfusion injury. Inflammation has a substantial contribution to this process. It has also a negative effect on myocardial function. Response of white

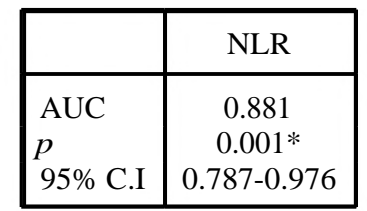

ROC curve for N/L ratio to predict RV dysfunction.

AUC : Area Under a Curve.

$p$-value : Probability value.

CI : Confidence Intervals.

\begin{tabular}{ccccc}
\hline \multicolumn{2}{c}{ Cut off Sensitivity } & Specificity & PPV & NPV \\
\hline NLR $>3.2$ & 82.61 & 89.19 & 82.61 & 89.19 \\
\hline PPV: Positive Predictive Value. NPV: Negative & Predictive & Value.
\end{tabular}

blood cells to different inflammatory triggers leads to secretion of pro-inflammatory cytokines such as tumor necrosis factor-alpha, interleukin-6, and $\mathrm{C}$-reactive protein. By the effects of these cytokines, contractile function of myocardium may decrease [10].

Neutrophils also secrete several proteolytic enzymes such as myeloperoxidase, acid phosphatase, and elastase which help destroying tissue structure, and neutrophil-driven microvascular obstruction can worsen ischemia and lead infarct expansion, as well [11]

Studies reported that lymphocytopenia was independently associated with mechanical complications and mortality in patients with acute STEMI [12].

As regard age and sex in our study there was no significant difference between the two groups as regarding age $(p$-value $=0.798)$ and sex $(p$-value $=0.914$ ). 
In our study most of the patients that presented with acute STEMI were females 36 patients $(60 \%)$, as regarding 2017 ESC guidelines ischemic heart disease develops on average 7-10 years later in women compared with men, MI remains a leading cause of death in women. Acute Coronary Syndrome (ACS) occurs three to four times more often in men than in women below the age of 60 years, but after the age of 75 , women represent the majority of patients [13].

\section{Regarding the neutrophil count:}

In this study there was a statistically significant difference between the two groups. Neutrophil count was higher in RV dysfunction group than normal RV function group, with $p$-value $=0.001$.

In concordance with the result of our study is the study conducted by Yaylak et al., [14], showed that neutrophil count was higher in Group II than Group I with $p$-value $=0.003$.

\section{Regarding the TLC count:}

In this study there was a statistically significant difference between the two groups. TLC count was higher in the RV dysfunction group than the other group, with $p$-value $=0.021$.

In contrast with the result of our study is the study conducted by Yaylak et al., [14], showed that there was no statistically significant difference between the two groups with $p$-value $=0.007$.

\section{Regarding the NLR:}

In this study there was a statistically significant difference between the two groups. N/L Ratio was higher in patients with RV dysfunction group than patients with normal RV function group, with $p$ value $=0.002$.

In concordance with the result of our study is the study conducted by Yaylak et al., [14], showed that NLR was higher in patients in Group II than Group I with $p$-value $=0.001$

\section{Regarding the LV ejection fraction $(E F)$ :}

In this study there was a statistically significant difference between the two groups as patients with RVD showed lowered EF than patients with normal $\mathrm{RV}$ function, with $p$-value $=0.001$.

In concordance with the result of this study is the study conducted by Rajesh et al., [15] with $p$ value $=0.05$ and Park, S.J et al., [16] with $p$-value $=0.001$.

In contrast with the result of this study is the study conducted by Yaylak et al., [14], Altintas et al., [17], Kanar et al., [18], who showed no statistically significant difference between both groups in $\mathrm{EF}$.

\section{Regarding $R V$ midway diameter:}

In our study there was a statistically significant difference between the two groups as patient with $\mathrm{RV}$ dysfunction showed larger RV midway diameter than patients with normal RV function, with $p$ value $=0.017$.

In contrast with the result of this study is the study conducted by Altintas et al., [17], Kanar et al., [18] and Smarz et al., [19], who showed no statistically significant difference between both groups regarding $\mathrm{RV}$ midway diameter.

\section{Limitations of the study:}

The study had some limitations. This is a singlecenter experience and represents a limited number of patients.

Duration of the study was relatively short.

\section{Conclusion:}

Neutrophil to lymphocyte ratio was an independent predictor of RVD in patients with acute inferior STEMI undergoing primary PCI or received thrombolytic therapy.

\section{References}

1- ZEHENDER M., et al.: Right ventricular infarction as an independent predictor of prognosis after acute inferior myocardial infarction. N. Engl. J. Med., 328: 981-8, 1993.

2- IBANEZ B., et al.: 2017 ESC Guidelines for the management of acute myocardial infarction in patients presenting with ST-segment elevation: The Task Force for the management of acute myocardial infarction in patients presenting with ST-segment elevation of the European Socie. Eur. Heart J., 39: 119-77, 2018

3- HARTLEY A., et al.: Trends in mortality from ischemic heart disease and cerebrovascular disease in Europe: 1980 to 2009. Circulation, 133: 1916-26, 2016.

4- GOLDSTEIN J.A.: Pathophysiology and management of right heart ischemia. J. Am. Coll. Cardiol., 40: 841-53, 2002 .

5- MEHTA S.R., et al.: Impact of right ventricular involvement on mortality and morbidity in patients with inferior myocardial infarction. J. Am. Coll. Cardiol., 37: 37-43, 2001.

6- KAYA M.G., et al.: Prognostic value of uric acid in patients with ST-elevated myocardial infarction undergoing primary coronary intervention. Am. J. Cardiol., 109: 48691, 2012.

7- AKPEK M., et al.: Relation of neutrophil/lymphocyte ratio to coronary flow to in-hospital major adverse cardiac events in patients with ST-elevated myocardial infarction 
undergoing primary coronary intervention. Am. J. Cardiol., 110: 621-7, 2012.

8- TOWNSEND N. et al.: Cardiovascular disease in Europe: Epidemiological update 2016. European Heart Journal, 37: 3232-45, 2016.

9- DAVIES M.J.: A macro and micro view of coronary vascular insult in ischemic heart disease. Circulation, 82: II38-I46, 1990.

10- MANN D.L. and YOUNG J.B.: Basic mechanisms in congestive heart failure. Recognizing the role of proinflammatory cytokines. Chest, 105: 897-904, 1994.

11- MADJID M., AWAN I., WILLERSON J.T. and CASSCELLS S.W.: Leukocyte count and coronary heart disease: Implications for risk assessment. Journal of the American College of Cardiology, 44: 1945-56, 2004.

12- DRAGU R., et al.: Predictive value of white blood cell subtypes for long-term outcome following myocardial infarction. Atherosclerosis, 196: 405-12, 2008.

13-REGITZ-ZAGROSEK V., et al.: Gender in cardiovascular diseases: Impact on clinical manifestations, management, and outcomes. Eur. Heart J., 37: 24-34, 2016.

14- YAYLAK B., et al.: Neutrophil/lymphocyte ratio is associated with right ventricular dysfunction in patients with acute inferior ST-segment elevation myocardial infarction. Cardiol. J., 23: 100-6, 2016.

15- RAJESH G.N., et al.: Echocardiographic assessment of right ventricular function in inferior wall myocardial infarction and angiographic correlation to proximal right coronary artery stenosis. Indian Heart Journal, 65: 522 8, 2013.

16- PARK S.J., et al.: Impaired RV global longitudinal strain is associated with poor long-term clinical outcomes in patients with acute inferior STEMI. JACC. Cardiovasc. Imaging, 8: 161-9, 2015.

17-ALTINTAS B., et al.: Impact of right ventricular diastolic dysfunction on clinical outcomes in inferior STEMI. Herz, doi: 10.1 007/s00059-01 7-463 1-9, 2017.

18- KANAR B.G., et al.: The impact of right ventricular function assessed by 2-dimensional speckle tracking echocardiography on early mortality in patients with inferior myocardial infarction. Clin. Cardiol., 41: 413-8, 2018.

19- SMARZ K., ZABORSKA B., JAXA-CHAMIEC T., MACIEJEWSKI P. and BUDAJ A.: Right Ventricular Dysfunction and Exercise Capacity After Inferior (Posterior) Wall Acute Myocardial Infarction. Am. J. Cardiol., 110: 784-9, 2012. 


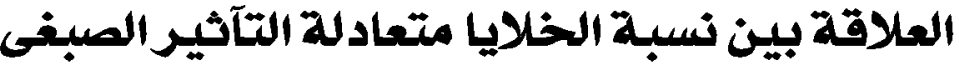

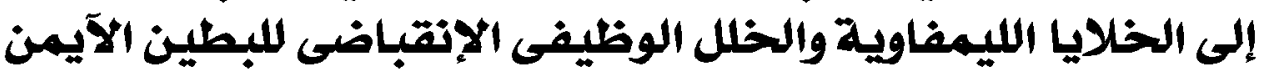

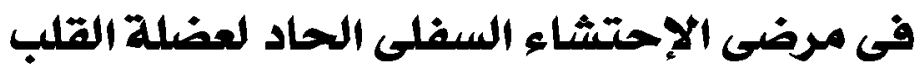

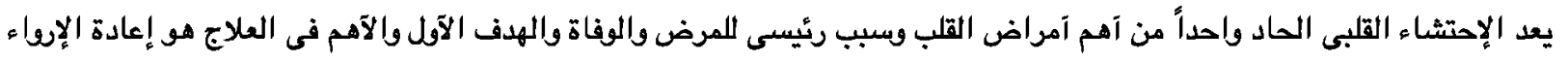
السريع إما عن طريق آدوية إذابة الجلطات آو إجراء القسطرة القراء القلبية العلاجية.

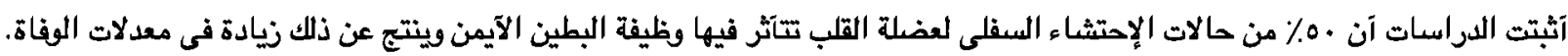

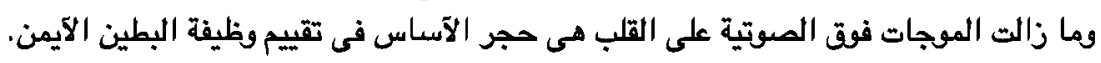

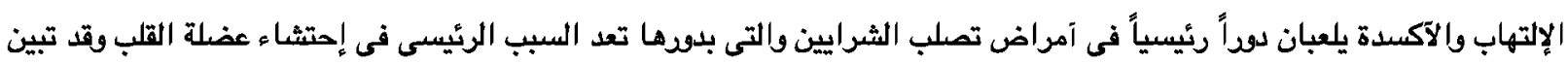

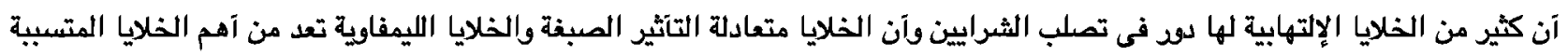
فى التصلب.

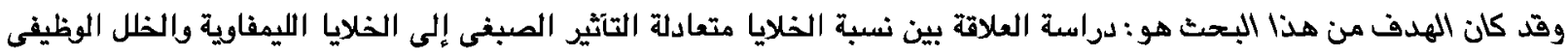

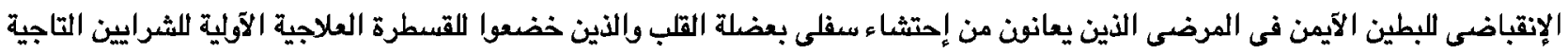
آو الذين تم إعطائهم عقار مذيب اللجلطة.

الهرضى وطرق البحث: آجريت هذه الدراسة على ستين مريضاً آصييوا بجلطة حادة في الثريان التاجي وتمت المعالجة عن طريق

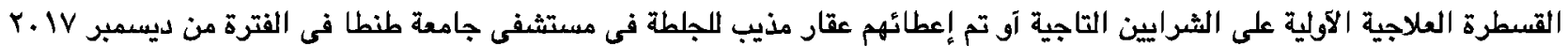

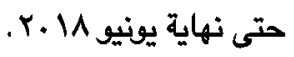

ومعايير الإدراج: مرضى الإحتشاء السفلى الحاد لعضلة القلب والذين تم علاجهم بالقسطرة القلية العلاجية الآولية على الشرايين التاجية آو تم إعطائهم عقار مذيب الجلطة. معايير الإسبتعاد: • • المرضى المصابون من قبل بإحتشاء حاد في عضلة القلب. • الفشل الكلوى بالمرحلة النهائية. • • آمراض الدم والكبد والقنوات المرارية. • • المرضى الذين يعانون من عدوى نشطة. • الآمراض السرطانية والذين تعرضوا حديثاً لجراحة آو حادث كبير . تم تقسيم المرضى إلى مجموعتين طبقاً للكفاءة الوظيفيبة الإنقباضية للبطين الآيمن للقلب:

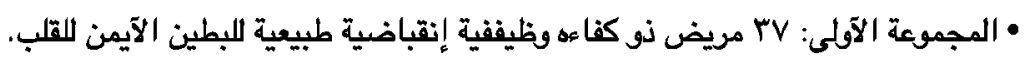

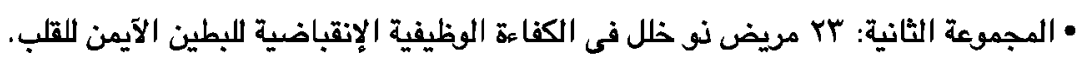

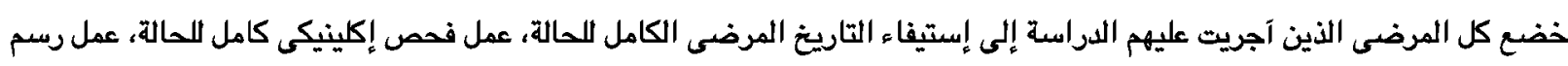

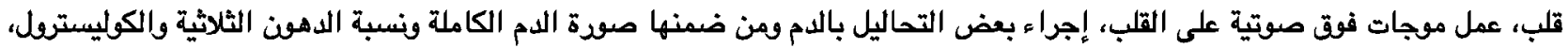

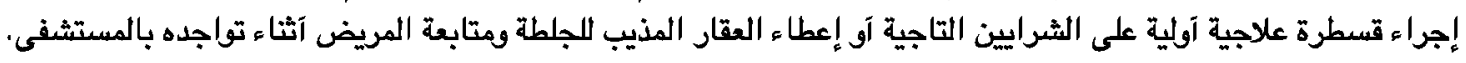

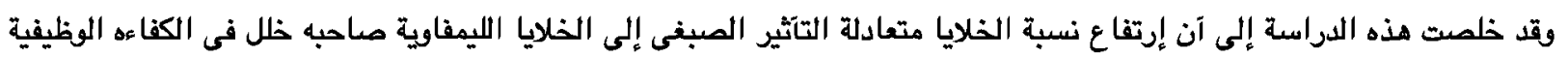

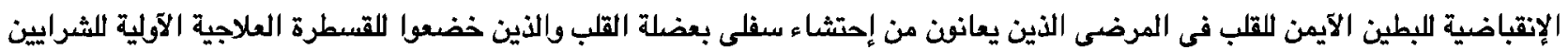
التاجية آو الذين تم إعطائهم عقار مذيب اللجلطة. 